\title{
Mark's story as oral traditional literature: \\ Rethinking the transmission of some \\ traditions about Jesus
}

\author{
P J J Botha \\ University of South Africa
}

\begin{abstract}
The interpretation of Mark's gospel is inextricably linked to a conception of the gospel's genesis. By basing his argument on an aspect of the 'oral formulaic theory' the author of this paper argues that Mark's gospel can be seen as an example of oral traditional composition. The primary asset of this perspective is that it provides an alternative to the tradition-redaction stalemate, current in Marcan studies. Some general implications are briefly discussed in conclusion.
\end{abstract}

\section{INTRODUCTION: THE ORIGINS OF THE MARCAN GOSPEL}

To see the Gospel of Mark as traditional material is certainly not a new observation. One can safely claim that it is almost standard practice, showing that, contrary to popular opinion, New Testament scholarship can reach consensus. However, what exactly is meant by claiming Mark to be 'raditional elicits widely diverging answers.

Mark is usually seen as a 'mixture' of tradition and redaction; tradition referring to stories, sayings, words and short descriptions that the evangelist (Mark) received from others. Most of these, or at least their essentials, are considered by scholars likely to be authentic. Redaction then refers to the additions and interpretations of the author himself, changing - more or less - the received parts into a so-called gospel.

How this sort of activity should be pictured historically receives very little attention in current research. Broadly speaking, two basic trends can be identified: emphasising continuity between tradition and redaction or alternatively underscoring creative interpretation.

The work of Birger Gerhardsson can be used as a convenient illustration of the first trend, in that the picture he draws of the history of the gospel traditions pro- 
bably reflects many scholars' unspoken assumptions. Gerhardsson (1979:77) emphasises the fact that there 'is certainly a complicated development behind our synoptic Gospels', 'a drawn-out and involved process' (Gerhardsson 1979:76). He argues for a balanced and extended perspective on the origin and history of the synoptic tradition, stressing the interaction between the whole and the parts, "between the total view [of the Jesus traditions] and the concrete formation of the material' (Gerhardsson 1979:76). However, he clearly sees the process as one of linear development: '...private notes were probably made rather early. As time went on, blocks of tradition, large and small, have been put together, and eventually the time was ripe for the first Gospel in our sense of the word' (Gerhardsson 1979:76). The development from the historical Jesus to gospei texts is, in Gerhardsson's view, the result of the disciples continuing what Jesus himself started. 'Turning to Jesus' oral teaching, we must reckon with the fact that he used a method similar to that of Jewish - and Hellenistic - teachers: the scheme of text and interpretation, He must have made his disciples learn certain sayings off by heart: if he taught, he must have required his disciples to memorize' (Gerhardsson 1961:328).

The Twelve, therefore, should be seen as a collegium, a 'rabbinic academy' supervising ó tóyos tov kupiou, that is 'the Holy Scriptures and the tradition from, and about, Christ' (Gerhardsson 1961:329-31) during the decades following Jesus' crucifixion. 'We must at all events take into account the fact that the actual transmission of such collections of traditions about Jesus was a distinct activity - a direct methodical delivery....The traditionist/teacher passed on the tractate, passage or saying to his pupil or pupils by means of continuous repetition; he taught the pupil to repeat it, after which he gave the required interpretation' (Gerhardsson 1961: 334).

Many scholars disagree with Gerhardsson on the extent of continuity between tradition and gospel text. In contrast, the unity of the text is posited and the allencompassing input of the final redactor is stressed. So the picture Mack (1988:322323) draws of the Marcan milieu probably speaks for several others: 'It was composed at a desk in a scholar's study lined with texts and open to discourse with other intellectuals.' Following the logic of this trend in gospel criticism, namely that the evangelists are authors, interpreting their received traditions, editorial activity can turn into active criticism of the tradition (e g Weeden 1971; Kelber 1985).

However, Gerhardsson's (1979:8) criticism against the form-critical scholars, 'that their work is not sufficiently historical' can also be extended to most discussions about Mark's creativity and/or literary activity. Those who understand the Gospel of Mark as 'narrative' or as 'literature' tend to assume that these analytical concepts can be divorced from their historically communicative contexts. As little as one can 
speak of other social conventions as if unrelated to concrete historical and cultural phenomena, just as little can one speak of 'narrative' or 'literature' without reference to text production, or outside social constructions such as authority, speaker, audiences, et cetera. It is in this sense that the questions of the transmission of (at least some) Jesus-traditions, the origins of the Marcan gospel and the interpretation of the text as we have it, are involved with each other.

The major assumption underlying usual thinking about the origins of the gospels is that tradition and redaction are distinguishable and therefore separable from each other. The assumption is used to explain certain characteristics of the texts, and this explanation is confirmed by thinking about tradition as accruing redaction. The traditional material is widely accepted as having been mainly oral material.

On the other hand, emphasising the pervasive role of interpretation, that is, socalled radical redaction criticism, or consistent narratological approaches, raises the issue of continuity with tradition or, put more simply, of invention. But even this approach still assumes that tradition can somehow be 'extracted', for otherwise it would not have been possible to recognise editorial activity.

Proving - or disproving - is of course, strictly speaking, impossible. Plausibility is, however, another matter. For instance, many studies have suggested that, seen within literary history, Mark's gospel stands quite close to popular, traditional texts (Reiser 1984:168; Votaw 1915:1-2; Schmidt 1923:127; Deissmann 1927:247; Smith 1955:38 n 23; Hadas 1950:266; Bilezikian 1977:19). The narrative lacks the consistency that one would expect from a sophisticated researcher - and although this is not a strong argument, it points away from Mack's picture. More importantly, that sort of picture does not fit into a historical reconstruction of text-production in antiquity (Kenyon 1951:66-85; Reynolds \& Wilson 1974; Künzl 1981:275-277; Eisenstein 1983:7; Boring 1979:62-63; Wiseman 1981:384-387; Graham 1987:30-36; Saenger 1982:370-373).

The critical question - how we should picture the transmission of the gospel traditions - is inescapable in solving some questions about Mark's gospel.

With this in mind it is of considerable importance to take into account the various criticisms brought against form criticism for not taking relevant sociological and linguistic research seriously enough (Sanders 1969:8-21; Brewer 1979:37; Güttgemanns 1979:193-211; Abel 1971; Gager 1974; Kelber 1980).

\section{TRANSMISSION AND COMPOSITION OF TRADITION}

If we were to see the Gospel of Mark as 'oral traditional literature' it would be possible to approach the complexities of the story with a terminologically different discourse and have the advantage of multi-disciplinary research as 'constraints'. 
When arguing for Mark to be approached as oral traditional literature, the use of the term 'oral' reflects the generally accepted oral background of the Marcan material as well as the historical situation of a scribal culture, heavily oriented towards orality. The term 'traditional' refers to the composition technique described by the oral formulaic theory.

In other words, the proposal is that the narrative making up the Gospel of Mark was not transmitted verbatim through memorisation, nor did it come into being as a creative reinterpretation; instead it was, as 'oral literature', composed and recited with slight variations at various performances, and the text as we now have it is but an instance, a reflection of one performance of that traditional process.

The so-called 'oral formulaic theory' or Parry-Lord theory is certainly one of the most widely used approaches to folklore and, more specifically, to traditions with a possible oral background (Foley 1987:xii; 1981a). Lord's work has been extended to materials composed in many different languages whose geography circles the entire globe (Renoir 1981:418; Foley 1985:17-70). To show the possible relevance of his work to the analysis and interpretation of the Gospel of Mark, it is necessary to discuss his exposition in some detail.

\subsection{Oral formulaic theory}

In the introduction to The singer of tales, Lord (1960:iii) claims that ' $[\mathrm{t}] \mathrm{his}$ is a book about Homer'. His purpose is more than simply to argue for possible orality with regard to the Homeric question; he aims at studying a specific type of oral communication and make the results relevant to the interpretation of other texts.

Basic to Lord's approach is that the transmission of oral traditional material does not happen by memorisation of fixed stories. Recounting traditions is done by dynamic, thriving, and unique narrations by specific and talented individuals, not by nameless tradents. This is the opposite of the claims of Formgeschichte (e g Schmidt 1923:166-174; Dibelius 1933:2-3). Traditional storytellers use phraseology and narrative themes provided by tradition and the particular story itself.

Lord (1978) himself applied some of his insights to the question of relationships among the synoptic gospels, suggesting the relevance of his research for understanding the traditional nature of the gospels.

In The singer of tales Lord develops his argument in two parts: a theoretical part defining 'oral epic song' which is then applied in the second part to Homer and other epic poetry. He bases his theory on the idea of Milman Parry (cf A Parry 1971:xxxii-xli) of utilising empirical research done among existing 'oral cultures' as comparative material and control for historical studies. Parry and Lord completed extensive fieldwork in this regard among the folk singers and poets of the Balkan 
states during the nineteen-thirties, and after the Second World War Lord and his students continued the studies. The theory is therefore based on comparative philology.

To discuss the theory in this context is not to claim that the gospels in any sense resemble poetic or epic literature, but to develop a framework for understanding the traditional nature of the gospels. The suggestion is that utilising and developing relevant theories from various disciplines can result in fruitful research as well as contribute to critical discussion of these theories.

\subsection{Some important characteristics of oral traditional composition, according to} Lord

\subsubsection{Composition in performance: the tradent as creative carrier of tradition}

The oral poet/singer does not plan his song beforehand. Composition happens in the performance itself: the singer himself is the tradition in the moment of delivery. He is more than an expert of the tradition; he is organically part of it: 'not a mere carrier of the tradition but a creative artist making the tradition' (Lord 1960:13). A performance is not a mechanical recital but something unique each time. Each performance is indeed a poem in its own right, stamped by 'the signature of its poet singer' (Lord 1960:4). The stories making up oral traditions are composed and 'recomposed' each time that they are recited.

A recording or transcription can never be the version of the song. The perfect or master version simply does not exist. In fact, the idea of an original version has, in this context and for this cultural phenomenon, little meaning (Lord 1960:100). Lord (1978:37) notes the 'textual fluidity' of 'oral traditional narrative'.

\section{The effect of the audience}

The interaction between listeners and singer has a powerful effect on the transmission of traditional material. A good singer must have considerable 'dramatic ability and narrative skill', demanding 'a marked degree of concentration' (Lord 1960:16), in order to capture the attention of an audience with words only. The 'setting' of oral composition demands both pace and flexibility. The specific techniques of oral composition enables the narrator/singer to keep the attention of his audience. These techniques consist of the use of formulas and themes. In this regard Rosenberg (1975:92) refers to the 'aesthetics of form', 'the various methods the artist employs to affect the traditional audience'. Style and diction are heavily influenced by the particular audience: the challenge of successfully performing before an audience creates a subtle interaction with the audience in which the epic story literally grows 'into' the audience. 


\subsubsection{Formulas and themes}

The concrete situation of the narrator/singer forces him to the extensive use of formulas and themes. These formulas and themes become part of his repertoire via his experience - of this and other 'stories' and songs - and his 'training'. 'Each such narrator, using the phrases and devices picked up from others, develops his or her own usage of lines and half-lines, clusters and passages, but always within the parameters of the tradition' (Lord 1978:37).

Formulas refer to fixed verbal and metrical combinations making up sentences and lines. Themes are 'repeated incidents and descriptive passages' (Lord 1960:4), a grouping of ideas (Lord 1960:69) stylistically constructed; something similar to what New Testament scholarship calls formgeschichtliche forms.

Formulas can be described as 'repetitions, stock epithets, stereotyped phrases': 'a group of words which is regularly employed under the same metrical conditions to express a given essential idea' (Lord 1960:30); 'the most stable formulas are those for the most common ideas of the poetry: names of actors and of places, and the time and description of actions' (Lord 1960:31-33). Formulas can be very flexible. The number of formulas used by a narrator/singer can be surprisingly small, since different formulations can be created in analogy to existing ones and almost endless possibilities can be employed by adaptation of current formulas (Lord 1960:36-37).

At issue is not the existence of formulas but the implications of their presence. The 'formulaic style of expression' points to the composition of the story. The narrator/singer must create his phrases by adapting known words or by using existing formulas. It is this ability that makes it possible for the singer of tales to remember immense epic stories without having a computer-like memory (Lord 1960:44-46).

An important characteristic of these compositional units is the so-called 'adding style': detailed descriptions with interruptions, many repetitions and insertions, as well as a paratactic style (Lord 1960:54-55, 65).

With regard to themes, Lord (1960:68) notes: 'Formulas and groups of formulas, both large and small, serve only one purpose. They provide a means for telling a story....[Reading any] collection of oral epic...the same basic incidents and descriptions are met with time and again....Following Parry, I have called the groups of ideas regularly used in telling a tale in the formulaic style of traditional song the "themes" of the poetry.'

Obviously there will be both 'minor' and 'major' themes (Lord 1960:71, 81) and smaller themes are often inserted into each other (one is immediately reminded of Mark's 'sandwich' structure). Lord also discovered that in 'a traditional poem... there is a pull in two directions: one is toward the song being sung and the other is toward the previous uses of the same theme. The result is...an occasional inconsis- 
tency...' (Lord 1960:94). The singer concentrates on the different episodes while seeing the whole in terms of his major themes; a tension creating at times some narrative inconsistencies (Lord 1960:95, 99).

A subject that Lord deems relevant for understanding the gospels is what he calls the 'traditional pattern of the life of the hero', a subdivision of 'mythic patterns' (Lord 1978:38-39). Should one see the gospels as oral traditional material, they

...must belong to a tradition of oral life story or biography...From the Old Testament we can see a repeated pattern of life stories of significant figures... Because the stories are of the leaders of Israel, both priestly and secular, we can also assume that these stories were told by certain members of the priestly or ruling class to the Israelites for cultic purposes. The story of Jesus would fit into such a tradition, but it would, of course, be a life story of the leader of another religious group, albeit a splinter one, told to members of this group for cultic purposes.

(Lord 1978:38)

Lord (1978:38, following Eliade) sees myth as 'sacred narrative in the full truth and efficaciousness of which people believe'. The historicity of a narrative in a gospel is something different from the question about the patterns in which a narrative is moulded.

Traditional narrators tend to tell what happened in terms of already existent patterns of story. Since the already existing patterns allow for many multiforms and are the result of oft repeated human experience, including spiritual experience, it is not difficult to adjust another special case to the flexibly interpreted story patterns....That its essence was consonant with an element in a traditional mythic [i e, sacred] pattern adds a dimension of spiritual weight to...[an] incident, but it does not deny [nor does it confirm, for that matter] the historicity of the incident.

(Lord 1978:39)

\subsubsection{The conservative aspect of traditional transmission}

Seen in the light of the narrator's/singer's 'training' and self-consciousness, oral tradition can be described as a conservative system. The narrator/singer sees him- 
self as 'defender of the historic truth of what is being sung' (Lord 1960:28). He will not admit to the existence of any differences between various 'editions' of his own version, or even between his version and what he originally heard from somebody else. The conviction is simply that he sings it 'exactly' as he himself heard it, even when it can be proved beyond doubt (with recordings) that variations do exist. That various singers perform the same epic story differently is due to the art of reciting and not because of any conscious effort by the narrator/singer. Through these performances the essence of the story is preserved, and must be preserved (Lord 1960: 28-29). The tradent 'is not concerned with transmission of text, but with transmission (a) of the art of composition and (b) of the story itself' (Lord 1978:37).

Although the tradition is carried by various persons and delivered on many occasions, it is necessarily conservative in nature, 'for it is of the necessary nature of tradition that it seek and maintain stability, that it preserve itself. And this tenacity springs neither from perverseness, nor from an abstract principle of absolute art, but from a desperately compelling conviction that what the tradition is preserving is the very means of attaining life and happiness' (Lord 1960:220).

Although each performance is unique, there are certain 'essential themes' making up the 'stable skeleton of narrative' - the Song or Epic as such. As long as the recital maintains these essential themes the narrative remains consistent and stable. Variations between performances is usually the result of (i) expressing the same thing differently (adapting to situation), (ii) extensions or embellishments by adding detail, (iii) adaptions acommodating local features, (v) deletions or (vi) replacement of themes (Lord 1960:123).

Traditional transmission in this sense is therefore a strong conservative force in protecting the essential or central themes of a tradition. The multiformity of a tradition is itself a preservative factor as variations are formed by 'forces' within the tradition (Lord 1960:120). Themes are of major importance: 'There is a close relationship between hero and tale, but with some tales at least the type of hero is more important than the specific hero' (Lord 1960:120).

\subsection{Objections}

The discussion points to some questions that need attention before we can apply these theoretical insights to the gospels in a meaningful way.

\subsubsection{Oral formulaic theory in context}

It is neither my intent, nor is this the place to put the oral formulaic theory and the critical discussion generated by its applications in its full context. Not that it is possible: In 1976 Miletich already remarked that studies 'relating in some degree to the 
oral theory...are legion and, to understate the case, have readily managed to defy bibliographical containment' (Miletich 1976:111 n 2). It is truly 'impossible to concur or quarrel with the theory's many, often brilliant, advocates or critics' (Edwards 1983:162 n 1). But it is important, and true to the spirit of fair interdisciplinary research, to discuss some significant aspects to demonstrate the necessity for a comprehensive grasp of the theory's strengths and limitations.

A hypothesis designed to explain recurring verbal and narrative units (epithets, formulaic expressions, ballad commonplaces) - which is usually explained as the result of either borrowing or memorial transmission - the oral formulaic theory attempts to specify the conventions responsible for the process by which language becomes traditional discourse. It also encompasses the role of various conventions of this process in narrative meaning. 'This focus on process, rather than the resultant text, or product, is the most important and innovative contribution of the theory, often overlooked by both adherents and detractors' (Edwards 1983:152). Lord has written that 'the Serbo-Croatian tradition can show us the importance of formulas and themes as the pragmatic basic composition of oral story verse' (Lord 1975:12; my italics). He views tradition as a unified system that generates a whole or subset of that tradition (Lord 1960:5; cf Edwards 1983:153).

Two aspects of the extensive critical discussion surrounding the oral formulaic theory need some elucidation.

The first aspect is the fact that it designates, strictly speaking, two theories (Bäuml 1984:32), the primary facet being compositional technique and oral performance, the secondary facet concerning textual characteristics and origins of written texts. Formulaic-thematic composition is so fundamental to Lord's approach that the theory is used to determine the possible orality of texts. Consequently, an important context for the application of the Parry-Lord hypothesis has been the assessment of oral or non-oral qualities of certain texts and questions of poetics as they relate to authorial origins of traditional texts. This aspect of the theory, 'quantitative analysis', has generated extensive critical debate.

It is feasible for Lord to claim the possibility of a 'quantitative analysis' because, while each performance of a singer of an oral narrative song may be different, there is a fundamental continuity both in the composition and the story line, which is preserved in spite of other variations. Such relative stability is due to the singer's use of formulas, formulaic expressions, and themes he has learned from his predecessors from a tradition of composition which may extend over many generations. This process of composition is not one of approximate or word-for-word memorisation. Based on his research he argues: 
- 'An oral text will yield a predominance of clearly demonstrable formulas' (Lord 1960:130).

" The presence of certain stylistic features: 'enjambement, the "adding" style' (Lord 1960:131); specifically metre and/or rhythm.

- 'While these elements of formula pattern and enjambement are vastly important for stylistic analysis in determining whether any text is oral or "literary," of greater significance for an understanding of the development of literary epic is the change that takes place in the ideas, in the themes presented in epic by a literate oral poet. The oral epic poet needs well-established themes for rapid composition' (Lord 1960:131).

However: "As with any theory, there are times when its doctrine must be followed absolutely and times when specifics must be altered in order to preserve the principles which underlie them' (Miletich 1976:114). In our case it would be foolish to attempt a 'quantitative formulaic analysis'. The departure from Lord's metrical standard would for the purposes of statistical analysis be a mis-appropriation of the theory (cf Miletich 1976:115).

The other aspect of the theory that has drawn extensive criticism is the theory's oral-improvisational foundation. Finnegan (1976:158-159) asserts that some oral materials are memorised, some fully improvised, and some fall somewhere in between. Similarly, but with more nuanced variations Opland (1980:75-79) also argues for a range of possibilities. Smith (1977) discusses some Indian epic traditions which, though variations during recitation do occur and underlying memorised formulas are contained, are non-improvisatory.

However, the theory does not want to cover every possible instance of oral material. Clearly, each case must be argued carefully to determine the degree of improvisation or memorisation involved. One should keep in mind that the singer of tales sings lengthy tales, as well as many tales on many occasions. There is no need to criticise the theory for not covering the Pabujis, or all African songs. Lord describes the typical situation of the singers that was studied and which influences the extent of the theory. The application of the theory should be related to performing in an informal context, a concern with extended narratives, and performers with an extensive repertoire of songs/traditions. Lord's (1975:8) call for 'a broader concept of oral tradition' is simply a claim that any one song or poem is part of many performances of many songs and poems by many performers with a broad geographic range (cf Foley 1981c:27).

For the purpose of interpreting Mark, the theory is not adopted primarily to assess the text's orality. I doubt whether the theory can be used to indicate orality 
outside epic poetry, and the orality of Mark can be substantiated with historical arguments. My interest is the compositional technique described by the theory: to discuss the possibility of seeing prominent characteristics of the Gospel of Mark as textual symptoms of this type of composition. It is, therefore, important to bear in mind that it is not the oral formulaic theory as such, but the process of traditional transmission that is of concern here. That the theory does explain some Marcan problems provides additional confirmation of the text's orality, but only in a secondary sense. The discussion so far is simply a springboard for further development.

\subsection{Comparable texts?}

Lord researched ballads and epic stories: 'narrative poetry'/'oral epic song' built up out of 'metrical lines and half-lines by means of formulas and formulaic expressions and of the building of songs by the use of themes' (Lord 1960:4). The gospels clearly are narratives, prose materials, much closer to 'oral history' than 'oral epic literature' (see the clear exposition of Lord 1978:33-34). But ' $\mathrm{t}$ ] always mutually exclusive, however. Oral history is sometimes incorporated into oral traditional literature. The telling of recent events by someone who is also an active narrator of the oral traditional literature of a culture tends to follow the patterns of traditional story... Thus oral history sometimes may be manifested in parts in oral traditional literature' (Lord 1978:36-37).

The question is about the essence of the theory: the traditional technique of composition. It is therefore interesting to note that the oral formulaic theory has been applied to widely diverging types of traditions.

Two factors influenced the wide dissemination of the original Parry-Lord hypothesis. On the one hand, 'A sign of the times in many of the studies on the functions of narratives is a liberal concept of tradition: for today's folklorists narration is not always just folktales or stories handed down for hundreds of years, but any stories reported in speech' (Lehtipuro 1980:16). This has been facilitated by the growing conviction that formulaic style is the linguistic characteristic of oral traditional communication (Wittig 1976:66; Gray 1971:289; Lord 1975:16).

On the other hand the theory offers many possibilities for comparative research. It provides a useful and verifiable methodological approach for understanding traditional literature whose original contexts have for all practical purposes been lost (Foley 1981b:262).

Naturally, the various developments affected aspects of the theory, for instance the perspective on oral traditional formula. Parry's (1971:272) original definition, 'a group of words which is regularly employed under the same metrical conditions to express a given essential idea' was aimed at the analysis of the composition of the 
Homeric texts. Lord used the same definition for various poetic epics - already a significant extension of the original concept. Nagy (according to Foley 1981b:263) queried the one-way relationship usually emphasised between metre and formula: the metre is generated by the formula rather than the other way round.

Studies focusing on formulaic style tend to emphasise the lexical and syntactical elements rather than mere rhythm. The conclusion that (parts of) the Homeric texts are 90 percent 'formulaic' (Lord 1960:142-144) 'is likely to be vacuously, and so uselessly, true' (Hainsworth 1964:157). Gray (1971:301-302) considers it a loss that oral formulaic theory did not originally note the high frequency of formulas in oral prose.

The research done by Dégh (1972) on folktales also leads to a description of composition in terms of the theory. According to her, a traditional narrative comes into being because traditional material '[is] fashioned from stable formulas commonly known to the tellers who adjust them to a basic outline kept together by a frame' (Dégh 1972:60). She sees formulas as (i) motifs - narrative units reflecting typical persons, scenes or events, (ii) frame notices, (iii) 'patterned figures of speech', and (iv) repetitions structuring the narrative apart from (ii) and (iii) (Degh 1972:61-66).

\subsubsection{The gospels as oral literature?}

Talbert (1978) voices a general objection against the use of the oral formulaic theory for gospel criticism when he emphasises that the gospels are "literary and interdependent'. 'Since mythic patterns are not the exclusive property of oral traditional literature, Lord's argument that the presence of such patterns in the Synoptics is an indication of the oral traditional character of these gospels must be regarded as inconclusive' (Talbert 1978:95). Talbert concludes from the word 'inconclusive' that it is impossible. However, Lord simply wanted to investigate options: 'I have searched in the gospels for evidence of oral traditional narrative mythic patterns, to see whether such patterns might have played a role in the formation of the gospels' (Lord 1978:90; my italics).

For Lord there can be little doubt that the gospels vary from one another to such an extent as to rule out the possibility that, as a whole, one could have been copied from another' (Lord 1978:90). The differences and similarities between the synoptics can be understood as a reflection of their oral background (cf Vansina 1985:159).

Talbert (1978:95) argues that 'the divergent wording is no obstacle to our viewing the Synoptic Problem as a literary one. Given the practices of the Hellenistic Age, it is exactly what one would expect'. He refers to Josephus's editing of biblical history in his Antiquitates. Talbert also claims that 'Tyson has shown that the agree- 
ment in order among the Synoptics is so high that a literary explanation is necessary' (Talbert 1978:96; my italics). But what makes this explanation necessary? Neither Tyson (1976) nor Talbert explains or substantiates this necessity. The implied assumption is apparently that some verbal agreement and structural similarity make anything other than literary dependency impossible.

Lord has shown in his many publications that oral traditions agree to a greater or lesser extent, as a result of many factors. Verbal agreement as such is no argument against oral characteristics.

It is problematic to compare a gospel such as Mark with Josephus (in contrast to Luke, cf Downing 1980, 1982). There are significant differences between the gospels, especially Mark's, and contemporary literature. But, more fundamentally: One should in principle not approach the synoptic question with twentieth-century ideas about textuality and literary activities. The possibilities of orality research for rethinking the synoptic problems are extensive (e g MacDonald 1986:23-25 on miracle stories).

Talbert's statement (1978:99), 'In Mediteranean antiquity an author could select from several sources and alternate them in patches or blocks without any hesitation' reflects literate, typographic assumptions about ancient authors. The sheer physical difficulties of having to cope with bulky manuscripts make Talbert's picture unlikely. The argument that 'Christianity emerged in a Mediteranean culture that was not illiterate...Books were produced on a scale theretofore unknown. A large reading public...' (Talbert 1978:101-102), though formally true, has little impact. The educational attainment of the average person in the Graeco-Roman world in terms of modern conceptions of literacy was negligible. Concepts such as illiterate, or literacy, are very much culture-specific, historically determined (Street 1984:8-11). The experience of books in a world where children were taught to recite Homer instead of reading the text, is quite different to ours (on this issue see Botha 1990).

To conclude this section, the validity of applying the oral formulaic theory to solving some questions generated by Mark's gospel cannot be doubted.

It is possible to argue for the orality of Mark's gospel on different grounds, especially historical ones, and the applicability of the oral formulaic theory lies in illuminating the traditional composition process. The extensive debate generated by the application of 'quantitative formulaic analysis' warns one that it is something of a dead end. The true impact of the theory does not lie in testing for orality. The immense complexities of human communication exclude a straightforward statistical measure of syntactical patterns as proof of orality (assuming that 'orality' is a useful, clear concept). 
The search is for an answer to the question about the transmission and origins of the Gospel of Mark. The oral formulaic theory provides the means to picture a narrator composing his story with the aid of his internalised grammar of tradition.

\section{MARK AS ORAL TRADITIONAL COMPOSITION}

How the Gospel of Mark came into being is a historical question and can only be answered by virtue of comparative criticism. So to pose the question is to ask whether the gospel reflects a formulaic style with thematic composition - in that case we are on the trail of Mark the traditional storyteller.

\subsection{Formulaic style in Mark}

The discussion about formulas within the application of the oral formulaic theory is wide-ranging and comprehensive. On the one hand the very existence of formulas has been questioned - at least their possible appearance outside the Homeric and Slavic song-epics. Furthermore, should one redefine the essence of formulas, this might lead to their becoming so abstract or general that all explanatory power is lost.

In this regard Rosenberg (1975) provides some valuable insights. He refers to the 'chaotic situation regarding definitions of the formula: every man his own definition' (Rosenberg 1975:96). His research on popular sermons leads him 'to question the usefulness of the very concepts of "formula" and "system". These terms, given us by Parry, connote something precise, mechanical and above all, autonomous. No doubt such an attitude is a concomitant of the philosophy which was the legacy of the New Criticism...' (Rosenberg 1975:96). 'With a fixed text in front of us we can define formulas as precisely or as liberally as we choose, but the singers are not thinking in terms of formulas and systems. One of the problems in defining these terms comes about because they are the scholar's attempts to impose a logical precision, a rationale, and a method where no such logical, rational method exists in the field - the singer's mind' (Rosenberg 1975:98). However, his conclusions are also highly relevant. Although the 'oral sermons' studied by him are far removed from Homer and southern Yugoslavia in both time and geography, he found consistencies with regard to diction and style. In his own words, the same theoretical assumptions were confirmed (Rosenberg 1975:76, 94).

Two developments are noteworthy in connection with the dissemination of the oral formulaic theory: the emphasis on the wide range of fixedness and novelty with regard to lexical and syntactical repetitions, 'familiar combinations of words, familiar syntactic patterns and so on' (Tannen 1982:6), and the focus on matters of con- 
tent, or what Culley (1976:9-10) calls 'stock episode, stock incident, or core plot... stringing together a series of standard elements'.

Tannen (1982:1-2) notes, for example, that '[f]ormulaic expressions [ = sayings, cliches, proverbs, and so on, the repository of received wisdom] function as wholes, as a convenient way to signal knowledge that is already shared. In oral tradition, it is not assumed that the expressions contain meaning in themselves....'

When looking at possible formulaic style in Mark, preferance should be given to phenomena typical of Mark's gospel, simply for reasons of control: An expression could definitely have been said differently, or with greater variation. Since I am interested in proving that Mark's use of the compositional process implied by the oral formulaic theory can explain most of the prominent characteristics of the Marcan gospel, it follows that I use the principle underlying the strict definition of formula.

Certain phrases in Mark can easily be identified as stylised expressions that may leap to the tongue, so to speak, when a new thought or saying needs to be formulat-

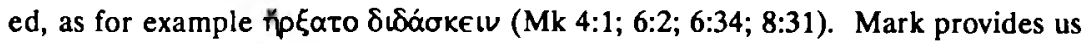
with several examples of regularly recurring, at times almost rhythmical, wording. So, for instance, the repeated use of the same verb in the same context (e g roportӨévaı in 8:6-7; ákoúєเV in 6:20; cf Neirynck 1972:77-81) or of compound verbs with

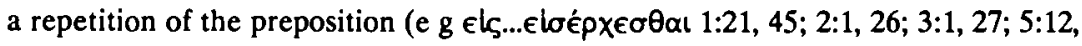

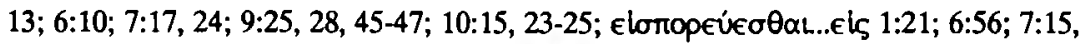
$18,19 ; 11: 2)$.

Initially, and in some applications of the oral formulaic theory the stylised use of epitaphs played an important part (Whallon 1969:71-116; Parry 1971:13-14). The use of a 'noun-epithet formula' 'suggests...habitual use or tradition' (Edwards 1983: 160). We do not find in Mark such stylised use of epitaphs. Apparently that is particularly characteristic of oral poetry. However, there is in Mark an intriguing stereotyped use of names. For example:

* I'́́xрos kaì 'Íákwßos kai 'I wáuvms (in this sequence) - 5:37, 9:2, 14:33.

- Andrew is always mentioned together with Peter - 1:16, 29, 3:8, 13:3.

- James is always mentioned together with John, and in this order - in addition to the textscited above see 1:29, 10:35, 41; compare 1:16-19, 3:16-18.

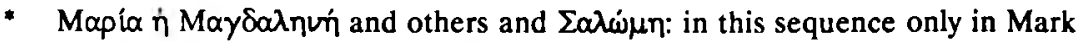
$15: 40,16: 1$.

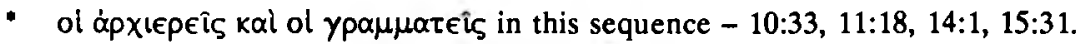

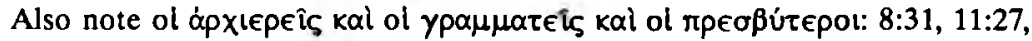
$14: 43,53,15: 1$.

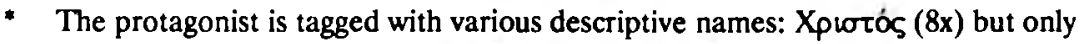

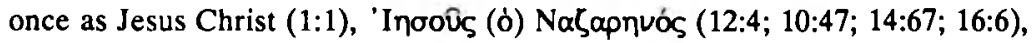




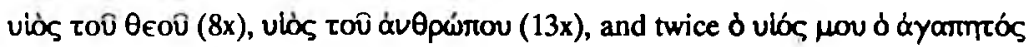
(1:11; 9:7; possibly $12: 6)$.

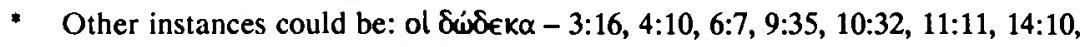
17, 20, 43; 'I I $13: 3,14: 26$.

Certain phrases suggest an almost involuntary repetition used as an introduction to narrative units or expressions. Examples are:

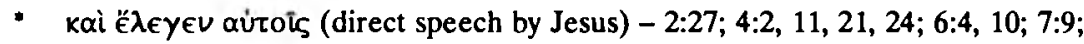
$8: 21 ; 9: 1,31 ; 11: 17$. In $4: 2,9: 31$ and $11: 17$ the phrase is combined with $6 \delta i \delta \alpha \sigma-$ kev. One can also point to kal $\lambda e$ eyel aưroîs and other variations $(\mathrm{e} \mathrm{g}$ kal

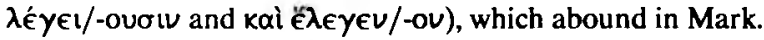

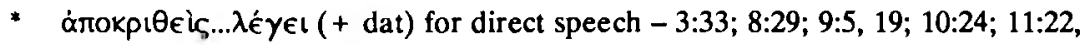
33; 15:2.

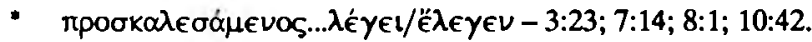

- It is quite possible that Mark's use of eú日ús $(1: 10,12,18,20,21,23,28-30,42$, $43 ; 2: 8,12 ; 3: 6 ; 4: 5,15-17,29 ; 5: 2,29,30,42 ; 6: 25,27,45,50,54 ; 7: 25 ; 8: 10 ; 9: 15$,

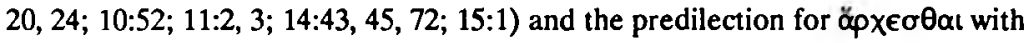
infinitive $(1: 45 ; 2: 23 ; 4: 1 ; 5: 17,20 ; 6: 2,7,34,55 ; 8: 11,31,32 ; 10: 28,32,41,47$; $11: 15 ; 12: 1 ; 13: 5 ; 14: 19,33,65,69,71 ; 15: 8,18)$ also reflects this aspect.

A prominent feature of Mark is a penchant for double expressions (e g 6:7; 14:19) and the habit of using series of threes (Neirynck 1972:110-112). Another interesting

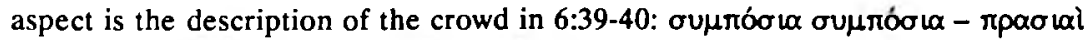

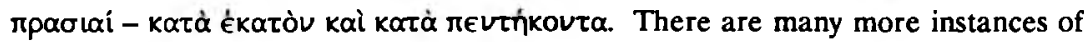
repetitive phrases in Mark which can be seen (heard!) as refrains, with an almost cliché-like use (Botha 1989:44-48; cf the extensive lists of Marcan 'redactional' characteristics compiled by Peabody 1987:35-113; Dschulnigg 1984:84-226). Thus, we find lexical and syntactical characteristics that can be interpreted as reflecting oral traditional composition.

\subsection{Mark and thematic composition}

The other essential aspect of oral composition identified by the Parry-Lord hypothesis is the performer's use of themes. That is, the 'passages' and 'incidents' identified by Parry and themes' named by Lord (1960:68), 'groups of ideas regularly used in telling a tale'. The repetition at stake here refers to typical events. Lord (1960:147), for example, identifies the 'theme of assembly' in the Iliad. He has also developed a typology of themes and analysed their internal structure and contents, distinguishing 
between 'composition theme' with a high degree of verbal agreement, and 'typescene' wherein one finds 'a given set of repeated elements or details, not all of which are always present, nor always in the same order, but enough of which are present to make the scene a recognizable one' (Lord 1975:21-23). Examples of both can be found in Mark.

Once again, it must be emphasised that for the purposes of this study the focus is on the possibility of thematic composition.

The first association in this regard is the well-known forms identified by Formgeschichte, especially pronouncement stories and various miracle stories. These themes are not about social situation, but about the need of a narrator when learning or developing a story. Themes allow the narrator to use structure and 'artistic imagination' in a situation of oral communication (Lord 1960:80).

\subsubsection{Motifs}

The role of motifs in Mark is noticeable in various ways. There are many instances of general motifs, shared with other narrative traditions of Mark's time, such as the proof of a miracle $(1: 31 ; 2: 12 ; 5: 42 ; 10: 52 ; 5: 13)$ or the command to secrecy $(1: 44$; 5:42; 7:36; 8:30; 9:9). This facet of Mark has been extensively discussed (e g Theißen 1974:57-89; Roth 1988:40-76; Robbins 1984, passim; Bultmann 1957, passim [e g 233-260 on miraculous and related motifs]; Smith 1975:25; Botha 1989:49).

\subsubsection{Thematic composition}

Mark also combines motifs into complex themes. What is relevant here is the comparable identity that certain pericopes share with each other, because of similar patterns or structures. Not only narrative elements but also narratives within the story influenced one another and could have - in terms of the oral formulaic theory 'created' one another.

Some examples:

* Confrontation with an unclean spirit: 1:23-26; 3:11-12; 9:25-26. Mark shows how historical knowledge (Jesus the exorcist: cf Jeremias 1971:91-96; Vermes 1973:65; Theißen 1974:279) 'exists' through a traditional theme.

* Calling disciples: 1:16-18, 19-20; 2:13-14.

- Healings: 5:21-24, 41-43; 7:31-37; 8:22-26.

- Sea-miracles: 4:35-41; 6:45-52. Not only verbal influence and similarity in 'typescene', but also corresponding underlying motifs such as rescue, identity (Pesch 1976:358 describes 6:45-52 as Epiphaniegeschichte) and puzzlement turn these stories into Marcan thematic composition. This is an apt illustration of how a well-known, general motif (cf Ps 105:9; 88:9; Job 9:8 [all LXX]; DioChrys Or 
3.30; Plut Caes 38.5-6; AelArist Or 42.10; 45.29-33; Luc Philops 13) is adopted by the Jesus-traditions and becomes a specific instance of Mark the storyteller's, extensive internalised narrative grammar. The theme reflects, as 'a subject unit, a group of ideas' not only this story but also the tradition as a whole (cf Foley 1981a:34) - an example of 'that distinctive process in which oral learning, oral composition, and oral transmission almost merge...facets of the same process' (Lord 1960:5).

- Bread miracles: 6:34-44; 8:1-9.

- Preparations: 11:1-7; 14:12-16. The reciprocal relationship between both pericopes has often been discussed in the dispute about Marcan redaction (e g Taylor 1966:536). In terms of the oral formulaic theory this points to the traditional creativity of the storyteller: 'the ability to compose and recompose the phrases for the idea of the moment on the pattern established' (Lord 1960:5).

- Love command: 12:28-31, 32-34. Jesus' answer is a fusion of certain Old Testament motifs (Dt 6:4-5; Jos 22:5; Lv 19:18). The motif generated a Marcan theme which was transformed in the scribe's response. Note the $\mu \in i \zeta \omega \nu$ tov

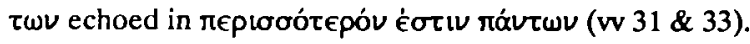

* Questioning: 14:60-64; 15:2-5. The role of thematic composition can be illustrated by a comment of Taylor (1966:563): 'No disciple was present at the trial, and for his information the Evangelist was dependent upon hearsay.' With various motifs (such as the silence of faithful - Ps 38:13-16; 39:10; Is 53:7-12, and the enemies who will see the victim again - WisSol 5.1-2; EthHen 62.3-5) the storyteller brings his knowledge of Jesus to life in front of his audience.

In these examples it is important to note the verbal repetitions and the structural similarities; thus, by virtue of 'both narrative sequence and verbal correspondence' (Foley 1981a:79-91), one can claim thematic composition. The relationships between the various elements of the individual themes are particularly relevant, illustrating a whole that is transformed each time. A given 'essential idea' is controlled by tradition, both allowing and limiting variation. Although the expression of a theme is clearly in flux, no individual appropriation of a theme destroys its continuity. Various applications of a theme are both autonomous and 'vom selben Typus ...und ist wohl als Variante beurteilen' (Bultmann 1957:228).

The passion predictions can also be added (Mk 8:27-32; 9:30-32; 10:32-34), as well as the parable of the sower and its interpretation (4:2-9, 13-21). 'The theme, even though it be verbal, is not any fixed set of words, but a grouping of ideas' (Lord 1960:69). 
Some themes display a considerable diversity in verbal expression, as can be seen in the 'sayings of Jesus' scenes (3:1-6, 20-30; 10:13-16; 11:15-19; 12:41-44; 14: 43-52). Greater resemblance is reflected by the 'epiphany' scenes (1:9-13; 9:2-10), the exorcisms, the various callings of disciples and the Sammelberichte, more correctly termed typifying compositions. 'Typisierend ist jedes erzählerische Arrangement, das Einzelmotive aus wenigen Erzählungen zum durchgehenden Zug der ganzen in der Rahmengattung beschriebenen Geschichte macht' (Theißen 1974:205). These typifying compositions $(1: 4-6,14-15,32-34 ; 2: 13 ; 3: 7-12 ; 6: 30-34,53-56 ; 10: 1)$ reflect very similar verbal construction (Egger 1976:27-38).

\section{PUTTING IT ALL TOGETHER}

\subsection{Summary}

The Gospel of Mark clearly has a formulaic style, with a stereotyped diction, many stock phrases and a repetitive technique. Scholes \& Kellogg (1966:51) remark that '[o]rally composed prose will necessarily be highly stylized', and I have argued that this is exactly what we have in Mark. A great part of Mark exists as thematic pericopes, 'types of events' reflecting one another stylistically and structurally, more or less.

In the perspective of the 'oral formulaic theory' the storyteller, Mark, had 'at his disposal a great pool of narrative elements - plot motifs, verbal formulae [including stock descriptions, dialogue exchanges, opening and closing runs...' (Bruford 1983: 103). The 'rules' according to which the elements combine with each other 'are different, less restricted because prose tales have no set metrical framework, from the rules followed by the "singer of tales"' (Bruford 1983:103).

So it is quite possible that the Gospel of Mark is a casual transcription of what had been performed orally. The Gospel probably reflects an improvisatory composition and re-composition within an informal context under the constraints of various traditions.

Tradition should not be seen as something permanent and unchanging. Nor does it refer to something older, more pure. Tradition is a dynamic process, intertwined with human self-interpretation and communication. Traditions are not things, moving by themselves. Human beings bring them to life and live through them. Taylor (1933:41, cf 41-43, 107) remarks: 'If the Form Critics are right, the disciples must have been translated to heaven immediately after the Resurrection.' I use his comment for a different purpose, but it illustrates the issue. Who talked about Jesus? Who knew about him? Robinson (1984) showed in an interesting investigation the very 'tiny group of friends and relatives from which it all began' (1984:110; Gerhardsson 1979:59-65). Short, anecdotal stories end up in a full-length 
story when someone wants to tell the story - and that need arose very shortly after Jesus' crucifixion. It is absurd to think that an extended narrative about Jesus became a reality outside the initial followers of Jesus and only after a long passage of time.

Jesus' primary purpose was not to establish local communities. He initiated a movement of itinerant radical prophets and teachers. The crucial figures in earliest Christianity were apostles, prophets and disciples travelling and relying on sympathisers in various places (cf Riddle 1938), such as Peter (Ac 8:14; 9:32; 10:20; Gl 2:11; 1 Cor 9:5). There are indications of other prophets such as Agabus (Ac 11:27; 21:10) moving between Antioch and Judaea. Travelling prophets and teachers were still the important authorities by the time of the writing of the Didache (Did 11-13). The

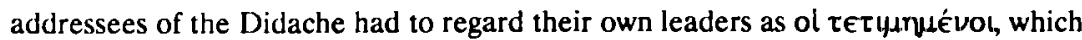
was similar to the regard given to travelling prophets and teachers (Did 15.2).

Papias (according to Eusebius: HE 3.39.15) tells us that the important church leaders of his time considered Peter to be the authority behind the Gospel of Mark. Rigg (1956:161) comments that 'what Papias seems to say seems to go against what on nearly every other ground modern scholarship has come to conclude about Mark', an opinion widely shared today. However, thinking in terms of oral traditional composition it is not strange to picture Peter as a travelling 'teacher' entrusting his Jesus-story to a 'disciple' at some stage. Although the connection with Peter was made to reinforce the authority and credibility of the Marcan gospel (Niederwimmer 1967:188; Körtner 1980) - at least, that is Eusebius' motive for citing Papias the picture seems very plausible. And that remains so whether Peter was involved or not, and independent of the reliability of the Papias-notice. If our analysis of Mark is correct, oral traditional composition presupposes very much the situation envisaged by Papias. In fact, Kürzinger (1977:252-258) is quite possibly on the right track when he describes Mark as a composition of xpeia without rákıc.

The role of Peter in the origins of Mark appears to me quite acceptable. The lack of documentary data leads one to underestimate the impact of Peter in the Jesus-movement (cf Dunn 1977:385).

That we have a written copy today is probably due to the traditional narrator having dictated his story at some stage. In fact, almost all writing done at the time was by dictation (e g Dio Chrysostomos Discourses 18.18; cf Skeat 1956; Stambaugh \& Balch 1986:40). Lord (1960:124-128) discusses some general theoretical aspects of formulaic poetic dictation (see also Whallon 1969:208-210). It is quite possible that the storyteller himself wrote and/or used a $\mu \epsilon \mu \beta$ póva (notebook - Roberts 1970:53-54; Kennedy 1978:148-154; Gerhardsson 1979:22-24). Dictation can have an effect on performance (Goody 1987:93-96) but, seen historically, this should not 
be overestimated in the first-century Mediterranean situation. Dictating to oneself and public performance were overlapping phenomena; medieval texts, for example, carry 'a heavy residue of primary orality' (Ong 1984:3; 1982:95; Lord 1986:41). Dictation for the purpose of ensuring the continuing existence of the tradition can be experienced by the storyteller as 'a public performance, no matter how intimate the recording session and even physical absence of the audience' (Bauman 1986:106). Lord found that the better singers among his informants produced their best performances in private situations; the recitations were more complete and complex (Lord 1953, 1960:124-128).

\subsection{Towards a better understanding of the Marcan traditions}

In a general sense it is clear that the whole topic of the verbomotor (Ong 1982:68) nature of antiquity, their oral-aural determined culture, leads to an extensive rethinking of many issues surrounding the texts we study (Ong 1977, 1981). More specifically, I would like to submit that this has some very important implications for both gospel criticism and Marcan research.

The immediate gain from the perspective of oral traditional composition is an alternative to the tradition/redaction cul-de-sac. The Gospel of Mark does not merely contain oral traditions, but is oral composition. Instead of approaching the Gospel either as a merging of various chronological, geographically influenced and theological parts, identifiable by what are taken as narrative inconsistencies, linguistic usages and historical infelicities, or as a work of great literary merit with a perfect dramatic structure and consistent characterisation, much like a modern topical author, ons should approach it as part of a traditional process. The linguistic situation pertinent to oral traditional composition explains the effective narration through an ostensibly inept style.

Mark's gospel is neither a series of poorly integrated stages involving a mélange of contributions from various tradents, redactors and interpolators, nor an individual act of poetic creation. Numerous elements of Mark take on new 'meanings'. The repetitions and thematic procedures have no overt theological or ideological basis. Many textual characteristics are simply involvement of oral mnemonics. The study of Dewey (1989, using Havelock 1984) illustrates this principle very well.

The next step is to analyse Mark's generic traits. Should one argue that Mark's story is a hero tradition (cf Botha 1989:63-77), various elements of the story should be seen as having their definite position and function as a result of that particular narrative plot (cf Jason 1977:275). Jesus is then pictured as the powerful teacher, and all elements work towards that depiction. Along these lines it is possible to 
avoid discussing Mark's story a-historically in the sense of 'Mark as literature' or 'Mark as narrative'.

It will be worthwhile to investigate the interwovenness of this story's religious aspects with a possible historical situation, such as that of radical, itinerant teachers. Like to the famous kuvikoi who travelled all over the Roman Empire (especially during the second half of the first century) with stick and knapsack, teaching and preaching' - beggar teachers who propagated 'the gospel of simplicity and independence, and comforted many in those troubled times by demonstrating that he who needs next to nothing, renounces all possessions, and keeps aloof from social entanglements, can live happily in the midst of war and disorder' (Von Fritz 1970:305) - the Marcan storyteller(s) performed their traditional story in many places. The importance of a story (and storytelling as such) about a hero teaching the way of God in the cultural equipment of a socially marginal group is self-evident. Comparative studies can highlight the value and role of stories and story-activity in the lives of traveller-people and the difficulties they endure.

If it had been possible to give Mark an electronic copy of his text stored on a flexible computer diskette it is obvious that he would have had very little comprehension of what he held in his hands. He would have lacked the conceptual framework and, obviously, the technological equipment and skills to convert that object to a communicative event. Similarly, but in reverse, we lack many aspects of the conceptual framework and technical skill to really turn the object known as 'manuscript Mark' into a communicative event. We must learn, at second hand, what it felt like to hear the Gospel of Mark, to sense the evocative interplay of his 'recreating' the traditions and feel the effect of his actualising of powerful motifs (cf Foley 1986a:1417).

\subsection{Some questions}

Insights from research done on orality and scribality obviously lead to a different conceptualisation of the various strata of the Jesus traditions. 'Perhaps the most basic and persistent problem confronted by students of oral literature is gauging the effect of the interplay of tradition and innovation, persistence and change, as manifested in the oral text' (Bauman 1986:78). We need to rethink the whole issue of creative innovation in early Christianity. In this regard Kellogg remarked: 'As a cultural ideal, such blending of "tradition" and "individual talent" is more appropriately applied to the criticism of Romantic and post-Romantic literature than to genuine oral literature, where...individual talent...is likely to be a function of our ignorance of the tradition' (Kellogg 1973:63). 
The limitations inherent in my study must also be noted. It is simply an exploratory starting point. This very analysis is in a certain sense still 'constitutive of literate values and literate linguistic bias' (Swearingen 1986:138). Therefore, one follow-up consequence must be a consistent approach of the text as work, bringing reception aesthetics to bear on the problem of a grammar of compositional units. Thus, moving away from phraseological formulas and the debates on what are or are not themes and motifs, addressing 'the units of oral traditional narrative...not as objective entities in themselves but as necessarily incomplete cues to be contextualized by an audience's subjective participation in the tale-telling process' (Foley 1986b: 216). The ideal is an informed involvement in which one strives to experience how 'the story-pattern provides a map for construing the narrative as a whole, the theme forecasts further developments both immediate and long-range, and the noun-epithet formula reaches far beyond its metrical slot to the mythic identity of its phraseological designate' (Foley 1986b:217).

'The application of oral theory to problems of literary history, sociology, and criticism of the Middle Ages promises to yield results far beyond the areas I have attempted to outline here' (Haymes 1981:354). As a final remark I would like to endorse this observation for the texts of early Christianity.

\section{Works cited}

Abel, E L 1971. The psychology of memory and rumor transmission and their bearing on theories of oral transmission in early Christianity. $J R$ 51, 270-281.

Bauman, R 1986. Story, performance and event: Contextual studies of oral narrative. Cambridge: Cambridge University Press.

Bäuml, F H 1984. Medieval texts and the two theories of oral-formulaic composition: A proposal for a third theory. New Literary History 16, 31-49.

Bilezikian, G G 1977. The liberated gospel: A comparison of the Gospel of Mark and Greek tragedy. Grand Rapids: Baker.

Boring, T A 1979. Literacy in ancient Sparta. Leiden: Brill.

Botha, P J J 1989. Die dissipels in die Markusevangelie. DD thesis, University of Pretoria.

--- 1990. Mute manuscripts: Analysing a neglected aspect of ancient communication. Theologia Evangelica 23/3,35-47.

Brewer, D 1979. The gospels and the laws of folktale. Folklore 90, 37-52.

Bruford, A 1983. Memory, performance and structure in traditional tales. An 37, 103-109. 
Bultmann, R 1957. Die Geschichte der synoptischen Tradition. 3. Aufl. Göttingen: Vandenhoeck.

Culley, R C 1976. Oral tradition and the OT: Some recent discussion. Semeia 5, 133.

Dégh, L 1972. Folk narrative, in Dorson, R M (ed), Folklore and folklife: An introduction, 53-77. Chicago: University Press.

Deissmann, A 1927. Light from the ancient east: The New Testament illustrated by recently discovered texts of the Greco-Roman world. London: Hodder.

Dewey, J 1989. Oral methods of structuring in Mark. Interp. 43, 32-44.

Dibelius, M 1933. Die Formgeschichte des Evangeliums. 2. Aufl. Tübingen: Mohr.

Downing, F G 1980. Common ground with paganism in Luke and in Josephus. NTS 28, 546-559.

-.- 1982. Redaction criticism: Josephus' Antiquities and the Synoptic Gospels. JSNT 9, 29-48.

Dschulnigg, P 1984. Sprache, Redaktion und Intention des Markus-Evangeliums: Eigentümlichkeiten der Sprache des Markus-Evangeliums und ihre Bedeutung für die Redaktionskritik. Stuttgart: Katholisches Bibelwerk.

Dunn, J D G 1977. Unity and diversity in the New Testament: An inquiry into the character of earliest Christianity. London: SCM.

Edwards, C L 1983. The Parry-Lord theory meets operational structuralism. JAF 96, 151-169.

Egger, W 1976. Frohbotschaft und Lehre: Die Sammelberichte des Wirkens Jesu im Markusevangelium. Frankfurt: Josef Knecht.

Eisenstein, E L 1983. The printing revolution in early modern Europe. Cambridge: Cambridge University Press.

Finnegan, R 1976. What is oral literature anyway? Comments in the light of some African and other comparative material, in Stolz \& Shannon 1976:127-166.

Foley, J M 1980. Oral literature: Premises and problems. Choice 16, 487-496.

--- 1981a. The oral theory in context, in Foley 1981c:27-122.

--- 1981b. Tradition-dependent and -independent features in oral literature: A comparative view of the formula, in Foley 1981c: 262-281.

--- (ed) 1981c. Oral traditional literature: A Festschrift for Albert Bates Lord. Columbia: Slavica.

--- 1985. Introduction, in Foley, J M (ed), Oral-formulaic theory and research: An introduction and annotated bibliography, 3-77. New York: Garland.

--- 1986a. Introduction, in Foley 1986b:1-18.

--- (ed) 1986b. Oral tradition in literature: Interpretation in context. Columbia: University of Missouri Press. 
Foley, J M 1986c. Tradition and the collective talent: Oral epic, textual meaning, and receptionalist theory. Cultural Anthropology 1, 203-222.

--- 1987. Series foreword, in Neusner, J, Oral tradition in Judaism: The case of the Mishnah, xiii-xv. New York: Garland.

Gager, J 1974. The gospels and Jesus: Some doubts about method. JR 54, 244-272.

Gerhardsson, B 1961. Memory and manuscript: Oral tradition and written transmission in rabbinic Judaism and earty Chritianity. Lund: Gleerup.

--- 1964. Tradition and transmission in early Christianity. Lund: Gleerup.

-.- 1979. The origins of the gospel traditions. Philadelphia: Fortress.

Goody, J 1987. The interface between the written and the oral. Cambridge: Cambridge University Press.

Graham, W A 1987. Beyond the written word: Oral aspects of Scripture in the history of religion. Cambridge: Cambridge University Press.

Gray, B 1971. Repetition in oral literature. JAF 84, 289-303.

Güttgemanns, E 1979. Candid questions concerning gospel form criticism: $A$ methodological sketch of the fundamental problematics of form and redaction criticism. 2nd ed, with additions. Pittsburgh: Pickwick.

Hadas, M 1950. A history of Greek literature. New York: Colombia University Press. Hainsworth, J B 1964. Structure and content in epic formulae: The question of unique expression. $C Q 58,155-164$.

Havelock, E A 1984. Oral composition in the Oedipus Tyrannus of Sophocles. New Literary History 16, 175-197.

Haymes, E R 1981. Oral composition in middle high German epic poetry, in Foley 1981c:341-346.

Jason, H 1977. Content analysis of oral literature: A discussion, in Jason, H \& Segal, D (eds), Patterns in oral literature. The Hague: Mouton.

Jeremias, J 1971. New Testament theology: The proclamation of Jesus. London: SCM.

Kelber, W H 1980. Mark and oral tradition. Semeia 16, 7-55.

-.- 1983. The oral and the written gospel: The hermeneutics of speaking and writing in the synoptic tradition, Mark, Paul and $Q$. Philadelphia: Fortress.

--- 1985. Apostolic tradition and the form of the gospel, in Segovia F F (ed), Discipleship in the New Testament, 24-46. Philadelphia: Fortress.

Kellogg, R 1973. Oral literature. New Literary History 5, 55-66.

Kennedy, G 1978. Classical and Christian source criticism, in Walker 1978:125-155.

Kenyon, F G 1951. Books and readers in ancient Greece and Rome. 2nd ed. Oxford: Clarendon.

Körtner, U H J 1980. Markus der Mitarbeiter des Petrus. ZNW 71, 160-173. 
Künzl, H 1981. Buch/Buchwesen III. Die Entwicklung von der Antike bis zur Neuzeit. TRE 7, 275-304.

Kürzinger, J 1977. Die Aussage des Papias von Hierapolis zur literarischen Form des Markusevangeliums. $B Z$ 21, 245-264.

Lehtipuro, O 1980. Folk-narrative research 1979. Anv. 36, 3-23.

Lord, A B 1953. Homer's originality: Dictated texts. TPAPA 84, 124-134.

--- 1960. The singer of tales. Harvard: University Press.

--- 1975. Perspectives on recent work on oral literature, in Duggan, JJ (ed), Oral literature, 1-24. Edinburgh: Scottish Academic Press.

-.- 1976a. Formula and non-narrative theme in South Slavic oral epic and the OT. Semeia 5, 93-105.

-.- 1976b. The traditional song, in Stolz \& Shannon 1976:1-15.

-.- 1978. The gospels as oral traditional literature, in Walker 1978:33-91.

..- 1986. The merging of two worlds: Oral and written poetries as carriers of ancient values, in Foley 1986b:19-64.

Macdonald, D R 1986. From audita to legenda: Oral and written miracle stories. Foundations and facets forum 2/4, 15-26.

Mack, B L 1988. A myth of innocence: Mark and Christian origins. Philadelphia: Fortress.

Miletich, J S 1976. The quest for the 'formula': A comparative reappraisal. Modem Philology 74, 111-123.

Neirynck, F 1972. Duality in Mark: Contributions to the study of the Markan redaction. Leuven: University Press.

Niederwimmer, K 1967. Johannes Markus und die Frage nach dem Verfasser des zweiten Evangeliums. ZNW 58, 172-188.

Ong, W J 1977. Interfaces of the word: Studies in the evolution of consciousness and culture. Ithaca: Cornell University Press.

-.- 1981. The psychodynamics of oral memory and narrative: Some implications for Biblical studies, in Masson, R (ed), The pedagogy of God's image: Essays on symbol and the religious imagination, 55-73. Chico: Scholars Press.

--- 1982. Orality and literacy: The technologizing of the word. London: Methuen.

--- 1984. Orality, literacy and medieval textualization. New Literary History 16, 12.

Opland, J 1980. Anglo-Saxon oral poetry: A study of the traditions. New Haven: Yale University Press.

Parry, A 1971. Introduction, in Parry, M 1971:ix-lxii.

Parry, M 1971. The making of Homeric verse: The collected papers of Milman Pary, ed by A Parry. Oxford: Clarendon.

Peabody, D B 1987. Mark as composer. Macon: Mercer University Press. 
Pesch, R 1976. Das Markusevangelium. 2. Teil- Einleitung und Kommentar zu Kap. 1,1-8,26. Freiburg: Herder.

Reiser, M 1984. Syntax und Stil des Markusevangeliums im Licht der hellenistischen Volksliteratur. Tübingen: Mohr. (WUNT 2.11.)

Renoir, A 1981. Oral-formulaic context: Implications for the comparative criticism of medieval texts, in Foley 1981c:416-439.

Reynolds, L D \& Wilson, N G 1974. Scribes and scholars: A guide to the transmission of Greek and Latin literature. Oxford: Clarendon.

Riddle, D W 1938. Early Christian hospitality: A factor in the gospel transmission. $J B L$ 57, 141-154.

Rigg, H A 1956. Papias on Mark. NT 1, 161-174.

Robbins, V K 1984. Jesus the teacher: A socio-rhetorical interpretation of Mark. Philadelphia: Fortress.

Roberts, C H 1970. Books in the Graeco-Roman world and in the New Testament. CHB 1, 48-66.

Robinson, J A T 1984. How small was the seed of the church? in Robinson, J A T, Twelve more New Testament studies, 95-111. London: SCM.

Rosenberg, B A 1975. Oral sermons and oral narrative, in Ben-Amos, D \& Goldstein, KS (eds), Folklore: Performance and communication, 75-101. The Hague: Mouton.

--- 1987. The complexities of oral tradition. Oral Tradition 2, 73-90.

Roth, W 1988. Hebrew gospel: Cracking the code of Mark. Oak Park: Meyer-Stone Books.

Saenger, P 1982. Silent reading: Its impact on late medieval script and society. Viator $13,367-414$.

Sanders, E P 1969. The tendencies of the synoptic tradition. Cambridge: Cambridge University Press.

Schmidt, K L [1923] 1985. Die Stellung der Evangelien in der allgemeinen Literaturgeschichte, in Hahn, F (Hrsg), Zur Formgeschichte des Evangeliums, 126-228. Darmstadt: Wissenschaftliche Buchgesellschaft.

Scholes, R \& Kellogg, R 1966. The nature of narrative. London: Oxford.

Skeat, T C 1956. The use of dictation in ancient book-production. PBA 42, 179-208.

Smith, J Z 1975. Good news is no news: Aretalogy and gospel, in Neusner, J (ed), Christianity, Judaism and other Greco-Roman cults, vol 1, 21-38. Leiden: Brill.

Smith, J D 1977. The singer or the song? A reassessment of Lord's 'oral theory'. Man 12, 141-153.

Smith, M 1955. Comments on Taylor's commentary on Mark. $H T h R$ 48, 21-64. 
Stambaugh, J E \& Balch, D L 1986. The New Testament in its social environment. Philadelphia: Westminster.

Stolz, B A \& Shannon, R S (eds) 1976. Oral literature and the formula. Ann Arbor: University of Michigan.

Street, B V 1984. Literacy in theory and practice. Cambridge: Cambridge University Press.

Swearingen, C J 1986. Oral hermeneutics during the transition to literacy: The contemporary debate. Cultural Anthropology 1, 138-156.

Talbert, C H 1978. Oral and independent or literary and interdependent? A response to Albert B Lord, in Walker 1978:93-102.

Tannen, D 1982. The oral/literate continuum in discourse, in Tannen, D (ed), Spoken and written language: Exploring orality and literacy, 1-16. Norwood: Ablex.

Taylor, V 1933. The formation of the gospel tradition. London: Macmillan.

--- 1966. The Gospel according to St. Mark. 2nd ed. London: Macmillan.

Theißen, G 1974. Urchristliche Wundengeschichten: Ein Beitrag zur formgeschichtlichen Erforschung der synoptischen Evangelien. Gütersloh: Gerd Mohn.

Tyson, J B 1976. Sequential parallelism in the synoptic gospels. NTS 22, 276-308.

Vansina, J 1985. Oral tradition as history. Madison: University of Wisconsin Press.

Vermes, G 1973. Jesus the Jew: A historian's reading of the gospels. London: Collins.

Von Fritz, K 1970. Cynics. OCD, 305.

Votaw, C W [1915] 1970. The gospels and contemporary biographies in the GrecoRoman world. Philadelphia: Fortress. (Originally in AJTh 14 [1915] 45-73, 217 49.)

Walker, W O (ed) 1978. The relationship among the gospels: An interdisciplinary dialogue. San Antonio: Trinity University Press.

Weeden, T J 1971. Mark - traditions in conflict. Philadelphia: Fortress.

Whallon, W 1969. Formula, character, and context: Studies in Homeric, Old English, and Old Testament poetry. Washington: Center for Hellenic Studies.

Wiseman, T P 1981. Practice and theory in Roman historiography. History 66, 374393.

Wittig, S 1976. Theories of formulaic narrative. Semeia 5, 65-91. 